\section{The Research System}

In its task of determining the criteria and methods that will enable university establishments to adapt more readily to the requirements of research, the Committee for Science Policy of the Organization for Economic Co-operation and Development has published Volume $1^{*}$ of The Research System which concentrates particularly on the situation in France, Fed. Rep. Germany and the U.K. The survey readily admits the difficulties of distinguishing between fundamental and other types of research. In the event, it was decided that the study should not restrict itself to 'nonoriented' research, free from any concern with utility. Whilst the survey recognises the recent change in the orientation of science policies arising from the new political concerns as to the possible contributions of science and technology to economic and social development, it states clearly that previous high hopes that the research system would lead to practical results were excessive.

It is deemed essential that more attention be paid to the understanding of the research system since whatever reforms the new approaches to science policy might produce, the speed of response is limited. Instant policies will not lead to instant results.

According to the survey, national demands for research cannot be defined in detail; efficiency seems to depend directly on the level of unity towards which the system, defined by the responsibilities assigned to re- search sponsors, tends spontaneously. One conclusion which will greatly interest the European Physical Society is that reforms in university research may fail...

'unless they take account of one dimension of research hitherto neglected: the international, and especially the European, dimension. All the countries should urgently recognise the need to internationalise research commissions, research teams, research programmes and research equipment. Such internationalisation is already within reach of the universities, and it is for them to initiate it. This will compel them to introduce a third major innovation (in addition to mobility and Europeanisation) : the formulation by each university of a policy determining its own structure and characteristics, aims and orientations, and thus its identity on the European scene, while permitting it to transcend or curtail within its boundaries the "parochalism" of individuals or departments.'

Because it is the individualistic conception of research which has coloured the whole systems and governed the trends of research in France, Fed. Rep. Germany and the UK, their behaviour is comparable : notably, none of the three countries has succeeded in overcoming the sluggishness of the universities. The link between teaching and research is considered from points of view of both personnel and institutions. In view of the increasing time needed for research, it is clear that teaching and research are each tending to become full-time. However, in order to ensure that there is easy transfer of personnel between such functions, it will be necessary to stress the value of basic teaching, so that no hierarchical system is established. In the same way, advanced research establishments should not be separated but should be part of the differentiated network of the research system.

There appear to be two pitfalls of organizing scientific effort in large laboratories with tasks defined for political ends, such as atomic energy. First, the administrative and political framework might divert the scientists from research and transform them into civil servants who concentrate upon financial, management and other bureaucratic factors. Secondly, the relatively short-term nature of politically expedient assignments creates serious problems when the tasks have been carried out.

The survey contains information and insight into The Research System, and it helps to identify the role of the individual scientist. However, it would hardly be worthwhile for the individual physicist to plough through the weighty and wordy volume, unless he is directly concerned with science policy. Moreover the extensive use of expressions such as 'non-oriented' and 'parochialism in science' certainly does not contribute to the transparency of the survey. Volume 2 will deal with smaller European countries, such as Belgium, Norway, The Netherlands, Sweden and Switzerland, and Volume 3 will compare the situation in Western Europe, Canada, USA and Japan.

* Available from O ECD Publications Office, 2, rue André-Pascal, F-75 Paris XViº.

\title{
Trends in Physics
}

The following Plenary Lectures from the Second General Conference of the European Physical Society in Wiesbaden, Fed. Rep. Germany, from 3-6 October 1972, will be published under the title 'Trends in Physics', expected to be 324 pp, A5.

$\begin{array}{ll}\begin{array}{l}\text { The origin of the universe } \\ \text { W. Kundt (Hamburg) }\end{array} & \begin{array}{l}\text { Chemical lasers and chemical reactions } \\ \text { induced by lasers }\end{array} \\ \text { Environment, scientific research and } & \text { A. Oraevsky (Moscow) } \\ \text { economic policy } & \text { Physics and society } \\ \text { J. Tinbergen (The Hague) } & \text { H.B.G. Casimir (Eindhoven) } \\ \text { Recent developments in high energy } & \text { On the way to a fusion reactor } \\ \text { physics } & \text { A. Schlüter (Garching) } \\ \text { L. van Hove (Geneva) } & \text { Physical aspects of displays } \\ \text { Nonlinear optics and short light pulses } & \text { S. van Houten (Eindhoven) } \\ \begin{array}{ll}\text { W. Kaiser (Munich) } & \text { Polarized neutrons and nuclei : } \\ \text { Applications of superconductivity } & \text { nuclear pseudomagnetism } \\ \text { B.B. Goodman (London) } & \text { A. Abragam (Paris) }\end{array}\end{array}$

Origin of biological information M. Eigen (Göttingen)

Lasers and the atmospheric sciences G. Fiocco (Frascati)

Atoms dressed by photons

C. Cohen-Tanoudii (Paris)

Exotic atoms

V. Telegdi (Chicago)

The computer and the teaching of physics

Y. Le Corre (Paris)

A selection of the Divisional Lectures will also be included.

The volume may be ordered now for Swiss Fr. 55.- (including postage.) Ind. Ord. Members of EPS. pay Swiss Fr. 50.-.

Please send your order now with payment to European Physical Society, Trends in Physics, PO Box 39, CH - 1213 Petit-Lancy 2, Switzerland 